\title{
Pasture growth on dairy farms in the Golden Bay and West Coast of the South Island
}

\author{
K.L. DAVIS ${ }^{1}$, N.A. THOMSON ${ }^{2}$, N.R. MCLEAN ${ }^{3}$, D.A. MCCALLUM ${ }^{4}$, \\ R.J. HAINSWORTH ${ }^{5}$, A.J. WARDS ${ }^{1}$ and R.G. BARTON ${ }^{1}$ \\ ${ }^{1}$ WestpacTrust Agricultural Research Station \\ ${ }^{2}$ Dairying Research Corporation \\ ${ }^{3}$ Agricultural Business Associates Hamilton \\ ${ }^{4}$ Dairy Farm Consultant, Raine Road, Mania \\ ${ }^{5}$ Livestock Advisory, Inglewood
}

\section{Abstract}

Pasture growth was monitored on 22 farms covering Golden Bay, Nelson, Murchison and West Coast districts during 1994 to 1997 . Pasture growth was measured monthly from grazed pasture using the rising plate meter (RPM) and the difference method. Pasture growth from the South Island sites were compared with growth at the WestpacTrust Agricultural Research Station (WTARS) in South Taranaki, measured by the more traditional trim method, and the difference method as used in the South Island study. The pasture growth recorded was then used by the dairy farm production model UDDER to predict the planned start of calving (PSC), stocking rate and milksolids (MS) production at maximum net financial return for seven districts. At WTARS the average pasture production recorded by the difference method was $16.3 \mathrm{t} \mathrm{DM} /$ ha and by the trim method, $12.9 \mathrm{tDM} / \mathrm{ha}$, the greatest difference between the two methods occurring in late spring/early summer. Pasture production on the south Island sites varied from 9.6 (Taramakau) to 16.1 (Grey Valley) t DM/ha. The major factor identified as influencing pasture growth, in an environment where rainfall for $91 \%$ of the sites exceeded $2000 \mathrm{~mm}$, was number of frosts. A multiple regression combining pasture production climatic and soil nutrient variables identified number of frosts and Olsen $\mathrm{P}$ as the major factors influencing pasture production $\left(\mathrm{R}^{2}=0.25\right)$. The use of the growth from seven districts by UDDER showed a marked variation in management practices and MS output. PSC varied from the first 10 days in August (Takaka, Nelson, Westport) to the last 10 days in August (Murchison). Stocking rates ranged from $2.0 \mathrm{cows} / \mathrm{ha}$ at Motueka to $3.3 \mathrm{cows} / \mathrm{ha}$ on an irrigated farm in the Nelson district. MS production/ cow differed little among districts and MS production/ha reflected stocking rate, ranging from $650 \mathrm{~kg} / \mathrm{ha}$ for Motueka to $1150 \mathrm{~kg} / \mathrm{ha}$ for Nelson. The main factor driving stocking rate and PSC was winter pasture production.
Keywords: climate, dairy production modelling, pasture production, soil fertility

\section{Introduction}

Knowledge of pasture growth assists in setting stocking rates that match pasture growth with cow requirements, an important element for achieving maximum efficiency on a dairy farm. Pasture growth curves assist in the planning of calving and drying off dates and seasonal pasture management (feed budgeting, conservation policies). Information on pasture growth also helps set realistic production targets and allows regions to be compared. With the development of the commercially available dairy farm simulation model, UDDER (Larcombe 1989), it is now possible to make realistic farm management decisions if pasture growth information is known (McLean 1993).

With consideration to the above, pasture growth studies were initiated in 1980 for Golden Bay and in 1994 for the West Coast of the South Island. A preliminary summary of the Golden Bay study was presented by McCallum (1993). Equivalent pasture measurements were also carried out at the WestpacTrust Agricultural Research Station (WTARS), in Taranaki. The aim of these three studies was to generate a database of monthly and annual pasture growth for different districts to assist dairy farm management decisions. Pasture production and dairy performance at WTARS were compared with pasture growth recorded from Golden Bay and the West Coast.

\section{Method}

The Golden Bay study consisted of 11 farms in 6 districts and the West Coast study involved 13 farms in 10 districts (Table 1). To enable comparison to be made across all sites the information collected over 3 years (1994-1997) will be presented.

Pasture growth was measured by the "difference" method (Lynch 1966) using the rising plate meter (RPM) and the equations published by L'Huillier \& Thomson (1988) to convert meter reading to herbage mass. In the 
summer-wet districts, the summer and early-autumn equations were not used. Two pasture cages $(2 \mathrm{~m} \times 1.5$ $\mathrm{m})$ were positioned within a paddock typical of each farm. The farmer was discouraged from using nitrogen (N) fertiliser on the measurement paddock. Three cages were also located within one paddock at WTARS to allow pasture growth comparisons to be made. The paddocks were grazed at the end of each month during spring, summer and autumn and at least once during winter. At the start of each month, the pasture inside each cage was measured with the RPM. Measurements were again made on a grazed area onto which the cage was rolled.

In the same paddock at WTARS that the RPM measurements were taken, pasture growth was also measured by the "trim" technique. Cages were placed on to an area trimmed by a mower, and production cuts taken with a mower at the end of each month. The method used was similar to that described by Roberts \& Thomson (1988).

Rainfall, soil temperature and frosts were recorded daily on participating farms. Farmers also recorded type and amount of fertiliser applied. Soil samples were collected on an annual basis for soil chemical analysis.

\section{Calving date and stocking rate optimisation}

Information collected from the Olsen $\mathrm{P}=40$ farmlet at WTARS in the 1996/97 season was used to standardise UDDER as a base to predict performance from the South Island pasture growth database. The question asked was, "what if the WTARS herd was given the pasture growth from the South Island district to produce milksolids (MS), instead of the Taranaki growth?" Farm performance was optimised on gross margin from a given set of inputs and operating costs. Inputs available were $100 \mathrm{~kg} \mathrm{~N}$ fertiliser/ha/year applied in two dressings: an early September application at a 10:1 response over 50 days and an April application at a 5:1 response over 80 days. The other inputs in this system were pasture conservation in the December and January period, and the feeding of the pasture supplements back to the cows through the periods of the year when feed was restricted. The milk price was set at $\$ 3.00 / \mathrm{kg}$ MS, the cost of running extra cows was $\$ 350 /$ cow and grazing off, $\$ 10$ / head/week.

Average pasture growth rates from selected farms and districts were run through UDDER to determine potential MS production, optimum stocking rates and calving dates at the maximum gross margin. Whataroa and Harihari growth rates were averaged and run through the program as one site owing to the similarity of their seasonal and annual DM production. Karamea and Westport growth rates were also averaged. Murchison, Takaka and Kokatahi/Kowhitirangi were put through
Table 1 Districts involved in West Coast and Golden Bay rateof-growth studies.

\begin{tabular}{llll}
\hline \multicolumn{1}{c}{ West Coast study } & \multicolumn{3}{c}{ Golden Bay study } \\
\hline Whataroa & $(1)$ & Takaka & $(3)$ \\
Harihari & $(1)$ & Collingwood - River flats (2) \\
Waitaha & $(1)$ & Collingwood - Pakahi & $(1)$ \\
Kokatahi/Kowhitirangi & $(3)$ & Murchison & $(4)$ \\
Taramakau & $(1)$ & Nelson (irrigated) & $(1)$ \\
Rotomanu & $(1)$ & Motueka & $(1)$ \\
Grey Valley & $(2)$ & & \\
Inangahua & $(1)$ & & \\
Westport & $(1)$ & & \\
Karamea & $(2)$ & & \\
\hline
\end{tabular}

( ) number of farms in each district

the simulation as individual sites. Motueka and Nelson were kept as separate sites. These two sites were similar in climate, location, altitude and fertility; however, the Nelson site used irrigation and the Motueka site did not.

\section{Regression analysis}

Multiple regression analysis was carried out to determine factors affecting seasonal and annual pasture production. Climatic factors and soil fertility were regressed against the pasture production.

\section{Results}

Rising plate meter vs mowing for pasture growth estimation

Total dry matter (DM) production as measured by the RPM at WTARS was $16270 \mathrm{~kg} \mathrm{DM} / \mathrm{ha}$ and by the mower, $12930 \mathrm{~kg} \mathrm{DM} / \mathrm{ha}$ (Table 2). The main differences in pasture growth occurred in spring (AugNov), the RPM recording $29 \%$ higher pasture production than the mower.

\section{Pasture growth in the Golden Bay and West Coast regions}

Average annual DM production from individual farms in the Golden Bay ranged from 9900 to $14100 \mathrm{~kg} \mathrm{DM} /$ ha and on the West Coast farms, from 9640 to 16120 $\mathrm{kg} \mathrm{DM} / \mathrm{ha}$. At WTARS the average annual DM production was $16270 \mathrm{~kg} \mathrm{DM} / \mathrm{ha}$ (Table 2).

In Golden Bay the annual rainfall ranged from 1148 to $2374 \mathrm{~mm}$ compared with 2199 to $6647 \mathrm{~mm}$ in the West Coast districts (Table 3). Average annual soil temperature and the average number of frosts per year varied greatly among districts. The variation for the West Coast and Golden Bay was similar.

Multiple regression analyses incorporating all climatic and soil test measurements showed the number of frosts and Olsen P to be the only significant factors 
Table 2 Monthly (kg DM/ha/day) and annual dry matter production (kg DM/ha) within districts averaged over the three years (1994-97).

\begin{tabular}{|c|c|c|c|c|c|c|c|c|c|c|c|c|c|}
\hline & Jan & Feb & March & April & May & June & July & Aug & Sept & Oct & Nov & Dec & Total \\
\hline \multicolumn{14}{|l|}{ West Coast } \\
\hline Whataroa & 54 & 52 & 36 & 29 & 5 & 7 & 5 & 12 & 15 & 43 & 51 & 56 & 11060 \\
\hline Harihari & 40 & 48 & 38 & 31 & 20 & 7 & 3 & 14 & 32 & 32 & 54 & 53 & 11260 \\
\hline Waitaha & 60 & 65 & 54 & 38 & 6 & 4 & 3 & 10 & 45 & 47 & 47 & 56 & 13160 \\
\hline Kokatahi/Kowhitirangi & 51 & 65 & 60 & 36 & 14 & 7 & 4 & 11 & 40 & 69 & 69 & 51 & 14440 \\
\hline Taramakau & 17 & 34 & 36 & 33 & 14 & 3 & 5 & 8 & 26 & 50 & 51 & 41 & 9640 \\
\hline Rotomanu & 67 & 68 & 42 & 20 & 4 & 6 & 4 & 12 & 30 & 48 & 52 & 53 & 12270 \\
\hline Grey valley & 58 & 73 & 73 & 40 & 18 & 6 & 3 & 12 & 37 & 79 & 72 & 61 & 16120 \\
\hline Inangahua & 45 & 65 & 74 & 58 & 4 & 8 & 10 & 7 & 50 & 81 & 82 & 38 & 15790 \\
\hline Westport & 55 & 53 & 60 & 44 & 12 & 15 & 3 & 26 & 38 & 69 & 59 & 33 & 14160 \\
\hline Karamea & 50 & 59 & 70 & 36 & 21 & 9 & 8 & 14 & 44 & 52 & 46 & 55 & 14070 \\
\hline \multicolumn{14}{|l|}{ Golden Bay } \\
\hline Takaka & 50 & 45 & 47 & 34 & 20 & 10 & 8 & 23 & 46 & 73 & 55 & 53 & 14100 \\
\hline Collingwood & 53 & 50 & 48 & 34 & 17 & 8 & 8 & 21 & 40 & 72 & 49 & 57 & 13890 \\
\hline Pakahi & 42 & 45 & 46 & 28 & 13 & 8 & 7 & 18 & 36 & 66 & 50 & 49 & 12390 \\
\hline Murchison & 55 & 49 & 41 & 23 & 11 & 4 & 4 & 13 & 36 & 76 & 71 & 57 & 13360 \\
\hline Nelson & 42 & 51 & 39 & 28 & 17 & 11 & 8 & 25 & 49 & 73 & 50 & 46 & 13320 \\
\hline Motueka & 16 & 18 & 22 & 20 & 8 & 7 & 5 & 15 & 39 & 84 & 58 & 33 & 9900 \\
\hline \multicolumn{14}{|l|}{ WTARS } \\
\hline plated & 52 & 29 & 45 & 35 & 18 & 7 & 9 & 34 & 67 & 98 & 85 & 55 & 16270 \\
\hline mown & 43 & 33 & 30 & 24 & 16 & 10 & 11 & 21 & 47 & 68 & 66 & 56 & 12930 \\
\hline
\end{tabular}

Table 3 Average annual climatic variables and soil fertility.

\begin{tabular}{|c|c|c|c|c|c|c|c|c|}
\hline & \multicolumn{3}{|c|}{ 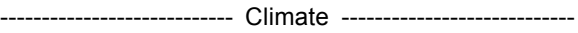 } & \multicolumn{5}{|c|}{ 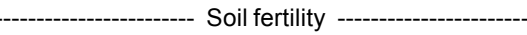 } \\
\hline & Rainfall (mm) & Soil temp $\left({ }^{\circ} \mathrm{C}\right)$ & \# Frosts/year & $\mathrm{pH}$ & $\mathrm{P}$ & $\mathrm{K}$ & $S$ & $\mathrm{Mg}$ \\
\hline Whataroa & 4050 & 11.0 & 32 & 6.0 & 39 & 4 & 22 & 11 \\
\hline Harihari & 3680 & 10.7 & 34 & 5.7 & 49 & 4 & 18 & 15 \\
\hline Waitaha & 3910 & 11.0 & 40 & 5.7 & 29 & 5 & 22 & 9 \\
\hline $\mathrm{K} / \mathrm{K}$ & 4040 & 10.8 & 41 & 5.7 & 31 & 4 & 28 & 8 \\
\hline Taramakau & 3610 & 10.8 & 48 & 5.4 & 47 & 6 & 30 & 10 \\
\hline Rotomanu & 5570 & 11.1 & 44 & 6.0 & 41 & 7 & 22 & 9 \\
\hline Grey Valley & 2100 & 11.4 & 34 & 5.7 & 57 & 7 & 25 & 10 \\
\hline Inangahua & 2530 & 12.4 & 17 & 5.5 & 58 & 8 & 16 & 15 \\
\hline Westport & 2890 & 13.4 & 16 & 6.1 & 45 & 6 & 15 & 9 \\
\hline Karamea & 2490 & 12.5 & 21 & 5.9 & 39 & 4 & 10 & 15 \\
\hline Takaka & 2370 & 11.3 & 30 & 5.7 & 57 & 17 & 21 & 21 \\
\hline Murchison & 2350 & 9.8 & 59 & 5.8 & 44 & 9.9 & 21 & 14 \\
\hline Nelson & 1150 & 10.9 & 48 & 6.8 & 37 & 10 & 17 & 136 \\
\hline Motueka & 1230 & 12.8 & 68 & 5.3 & 60 & 8 & 41 & 29 \\
\hline WTARS & 1057 & 12.2 & 33 & 5.5 & 40 & 9 & 18 & 35 \\
\hline
\end{tabular}

influencing pasture growth (Table 4). Total autumn/ winter pasture production was influenced largely by the average number of frosts per year $\left(\mathrm{R}^{2}=0.44\right)$. The variation in autumn/winter growth explained $68 \%$ of the variation in annual pasture production.

Table 4 Results of multiple regression of climatic factors and soil fertility against pasture production $\left(R^{2}=0.25\right)$.

\begin{tabular}{lccc}
\hline Variable & Parameter Estimate & Standard Error & $\mathrm{P}$ value \\
\hline Intercept & 13507.7 & 1373.4 & 0.0001 \\
Frosts & -45.8 & 19.5 & 0.0288 \\
Phosphate & 44.3 & 27.6 & 0.1239 \\
\hline
\end{tabular}

\section{Calving date and stocking rate optimisation}

The optimisation to achieve the maximum net margin for given input and management constraints resulted in the planned start of calving (PSC) varying between 1 and 30 August, stocking rate between 2.0 and 3.4 cows/ ha and $\mathrm{N}$ fertiliser use from 0 to $60 \mathrm{~kg} \mathrm{~N} / \mathrm{ha}$ (Table 5). At optimum net revenue, the difference in MS production between districts was $520 \mathrm{~kg} \mathrm{MS} / \mathrm{ha}$. In general, with movement south, PSC was later, and stocking rate, production/cow, production/ha and net returns all declined.

The optimisation for Motueka and Nelson farms were generated to assess the benefit from irrigation for 
Table 5 UDDER predictions of farm performance at optimal gross margins.

\begin{tabular}{|c|c|c|c|c|c|c|c|}
\hline District & $\mathrm{PSC}^{*}$ & $\begin{array}{c}\text { SR } \\
\text { (Cow/ha) }\end{array}$ & $\begin{array}{c}\text { Lactation } \\
\text { Days }\end{array}$ & $\begin{array}{c}\mathrm{N} \text { fertiliser } \\
\text { (kg/ha) }\end{array}$ & $\begin{array}{c}\text { Milksolids } \\
\text { (kg/cow) }\end{array}$ & $\begin{array}{c}\text { Milksolids } \\
\text { (kg/ha) }\end{array}$ & $\begin{array}{l}\text { Net margin } \\
\qquad(\$ / \text { ha })\end{array}$ \\
\hline Takaka & Aug. 1 & 3.1 & 250 & 20 & 342 & 1060 & 1562 \\
\hline Motueka & Aug. 2 & 2.0 & 240 & 0 & 325 & 650 & 725 \\
\hline Nelson & Aug. 1 & 3.4 & 250 & 40 & 337 & 1150 & 1422 \\
\hline Murchison & Aug. 3 & 2.9 & 230 & 20 & 315 & 910 & 1243 \\
\hline Westport & Aug. 1 & 3.3 & 250 & 50 & 334 & 1100 & 1480 \\
\hline Whataroa/Harihari & Aug. 2 & 2.5 & 240 & 60 & 336 & 840 & 1094 \\
\hline * PSC in 10-day intervals & Aug & 1-10 August & Aug. 2, & 0 August & Aug. 3, 21 & ugust & \\
\hline
\end{tabular}

two otherwise similar districts. The irrigated farm carried $1.4 \mathrm{cows} /$ ha more than the non-irrigated. The PSC at Motueka was 10 days later than Nelson which was reflected in a lactation 10 days shorter. With the higher stocking rate and longer lactation, the Nelson irrigated farm produced $500 \mathrm{~kg} \mathrm{MS} /$ ha more than the non-irrigated farm at Motueka.

\section{Discussion}

\section{Rising plate meter vs mowing for pasture growth estimation}

Pasture production measured by the difference method and the RPM was $25 \%$ greater than estimated by the more traditional trim method (Table 2); the greatest difference in the estimates occurred in spring/early summer. Thomson (1998) reported a similar result when the trim method was compared with the difference method using calibrated visual estimates of herbage mass. Pasture growth studies conducted in the Kowhitirangi and Ahaura districts on the West Coast using a trim technique (Morton \& Paterson 1982) reported Kowhitirangi $8100 \mathrm{~kg} \mathrm{DM} / \mathrm{ha}$ and Ahaura 9400 $\mathrm{kg} \mathrm{DM} / \mathrm{ha}$. This estimate of pasture production is more in line with the average MS production for Westland of $500 \mathrm{~kg}$ MS/ha (LIC 1995/96) than the average pasture production of $14440 \mathrm{~kg} \mathrm{DM} / \mathrm{ha}$ for Kowhitirangi and $16120 \mathrm{~kg} \mathrm{DM} / \mathrm{ha}$ for the Grey Valley (closest site to Ahaura) reported in this study. MAF Tech (1988) reported from a farm monitoring study conducted in Kowhitirangi during 1884-1987 an annual pasture production assessed by the difference method (using visual estimates) of $11500 \mathrm{~kg} \mathrm{DM} / \mathrm{ha}$. Considering pasture and MS production from WTARS, the average MS production from the experimental $\mathrm{P}=40$ farmlet of $1050 \mathrm{~kg} / \mathrm{ha}$ was more in line with the difference than the trim estimates of pasture production, using the conversion of pasture DM to MS of 14:1. Also, UDDER gave a good estimate of performance from the WTARS farmlet using pasture growth estimated by the difference method.
It is assumed the trim (mowing) method underestimates pasture production, particularly in spring, possibly because of greater defoliation of the most rapidly growing part of the grass - the stem and flag leaf (Reid 1967) - which occurs more under mowing than grazing. To provide a more meaningful estimate of pasture production under grazing, we pasture production assessed by the difference method relates to dairy farm performance better than the trim method.

\section{Pasture growth in the Golden Bay and West Coast regions}

The multiple regression resulted in the generation of two models. The first was that with frosts alone explaining $16 \%$ of variation. The second model was where frosts and Olsen P status together explained 25\% of the variation in annual pasture production. This effect is highlighted in Figure 1, which compares pasture growth from a relatively frosty site (Rotomanu; average 44 frosts/year) with a less frosty site (Westport; average 16 frosts/year). Soil fertility had less of an effect, but as the average Olsen P values (29-60) were all above optimum (20-25) for maximum pasture production (Roberts et al. 1994), this was not surprising. However, despite the high Olsen P status, Olsen P still had a small positive influence on pasture production. In districts with high annual rainfall such as Golden Bay and in particular on the West Coast, rainfall had no effect on pasture production.

Rainfall was not one of the key factors affecting pasture production, but it is interesting to compare the Nelson and Motueka sites. These two districts (one monitored farm in each) are relatively close together, with similar climatic conditions. The Nelson site used irrigation but the Motueka site did not. Figure 2 shows quite clearly the effect of irrigation on summer pasture production. This effect on pasture production was reflected in an increase of $500 \mathrm{~kg}$ MS/ha (Table 4). As Motueka had more frosts, all the differences in farm performance cannot be attributed to irrigation alone. 
Figure 1 Comparison of seasonal DM production from a cool (Rotomanu) and mild (Westport) location.

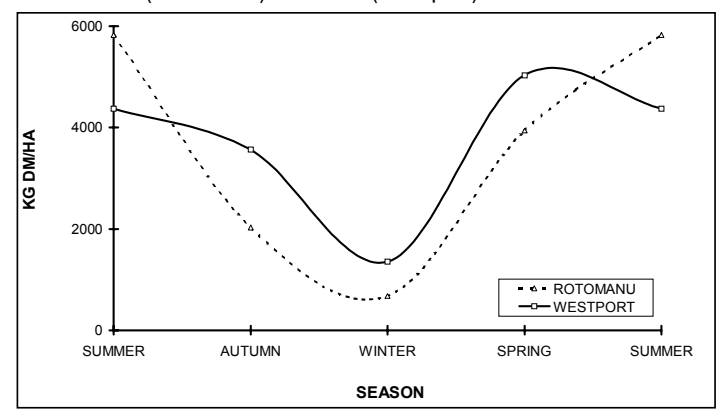

Figure 2 Comparison of pasture growth of an irrigated (Nelson) and non-irrigated pasture (Motueka).

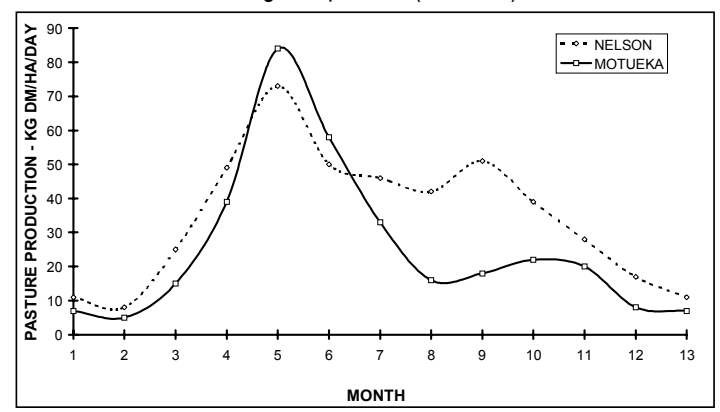

\section{Calving date and stocking rate optimisation}

Through the use of UDDER, pasture production information from a number of districts was able to be converted into dairy farm performance targets. When UDDER was set to optimise net financial returns for a particular district under standard management constraints, regional differences in SR, PSC, MS production and net financial returns were established. The main physical limitation controlling stocking rate was winter pasture production. With the budgeted low responses to $\mathrm{N}$ fertiliser in the model, and slow pasture growth through June and July, the average farm cover needed to increase in autumn to ensure there was sufficient pasture for spring. For the summer-wet districts the general trend was for MS production and net returns to decline the further south the district. The lowest MS production and net returns were, however, recorded for Motueka. This was in part owing to the large number of frosts restricting autumn/winter growth, but also to the low rainfall reducing the potential for summer growth. Overall, regression analyses showed a relationship $\left(\mathrm{R}^{2}\right.$ $=0.46$ ) between number of frosts and net financial returns, confirming that the main factor driving dairy farm performance for the northern and West Coast regions of the South Island was number of frosts.

\section{Conclusion}

There was a $3400 \mathrm{~kg} \mathrm{DM} / \mathrm{ha}$ difference observed between the difference and trim methods of pasture growth estimation The RPM and the difference method was considered a good technique for the purpose of dairy pasture growth studies.

Annual pasture production was in the main influenced by the number of frosts (a decline of $46 \mathrm{~kg}$ $\mathrm{DM} /$ ha for each additional frost) and Olsen P soil test value (an increase of $44 \mathrm{~kg} \mathrm{DM} / \mathrm{ha}$ for each unit increase in Olsen P). From the estimates made of pasture growth assessments for various districts, the optimum stocking rate and calving date under full pasture utilisation using the computer model UDDER were established. From the computer simulation runs, poor winter pasture growth was the main factor influencing decisions on stocking rate, calving date and $\mathrm{N}$ fertiliser use, which was reflected in financial returns.

\section{ACKNOWLEDGEMENTS}

Farmers contributing to the database by allowing their farms to be sites in the study and by collecting monthly pasture data and daily climate data. Tasman Milk Products Limited for their sponsorship for the Golden Bay Rate of Growth trial over the past 8 years. Westland Dairy, Ravensdown and AgResearch for their sponsorship in the West Coast Rate of Growth study for the 3 years, 1994-97.

\section{REFERENCES}

Larcombe, M.T. 1989. The effects of manipulating reproduction on the productivity and profitability of dairy herds which graze pasture. PhD thesis, Melbourne University.

L'Huillier, P.J.; Thomson, N.A. 1988. Estimation of herbage mass in ryegrass-white clover dairy pastures. Proceedings of the New Zealand Grassland Association 49: 117-122.

Lynch, P.B. 1966. Conduct of Field Experiments. Bulletin No. 399. New Zealand Department of Agriculture: pp. 71-85.

MAF Tech 1998. Dairy Farm Monitoring Project 19841987. A combined MAF Tech New Zealand Dairy Board publication: p. 20.

McCallum, D.A. 1993. Pasture growth in the golden Bay. Dairyfarming annual 45: 14-19.

McLean, N.R. 1993. Applying management strategies to increase profit. Dairyfarming annual 45: 142150.

Morton, J.D.; Paterson, D.J. 1982. Seasonal distribution of pasture production in New Zealand XV11. 
Kowhitirangi and Ahaura, West Coast, New Zealand. New Zealand journal of experimental agriculture 10: 245-252.

Reid, D. 1967. Studies in the cutting management of grass-clover swards. V The effect of changes in the closeness of cutting at different times of the season on the yield and quality of herbage from a perennial ryegrass-clover sward. Journal of agricultural science, Cambridge 68: 249-254.

Roberts, A.H.C.; Morton, J.; Edmeads, D.C. 1994. Fertiliser use on dairy farms - lower North Island/ South Island. Dairying Research Corporation publication: 13 .

Roberts, A.H.C.; Thomson, N.A., 1984. Seasonal distribution of pasture production in New Zealand XVII. South Taranaki. New Zealand journal of experimental agriculture 12: 83-92.

Thomson, N.A. 1998. Thirty-six years of dairy research in Taranaki. Dairyfarming annual 50: 167-186. 